\title{
Effect of Zircon and Aluminum Dross on Sinterability and Properties Al-Matrix Composites
}

\author{
M F Zawrah ${ }^{a^{*}}$, Ibrahim M. Hassab Allah ${ }^{\text {b }}$ Mousab M. A. Mohamed ${ }^{c}$, Moataz H. Ata ${ }^{\mathrm{d}}$ \\ ${ }^{a}$ Refractories, Ceramics and Building Materials Department, Center of Excellence for Advanced Science, Nanomaterials group, National \\ Research Center, Dokki, Cairo, Egypt \\ ${ }^{b}$ Mechanical Engineering Department, Faculty of Engineering, Assiut University, Assiut, Egypt \\ ${ }^{c}$ Production Department, Industrial Technical Institute, Sohag, Egypt \\ ${ }^{d}$ Production Department, Faculty of Industrial Education, Sohag University, Sohag, Egypt
}

\begin{abstract}
In the present study, Al-matrix composites reinforced by zircon and aluminum dross were prepared by powder metallurgy after sintering at $500^{\circ} \mathrm{C}$. The effect of different percentages of zircon i.e., 2, 4, 6, 8 and $10 \mathrm{wt}$ \%, and aluminum dross i.e., 5 , 10,15 , and $20 \mathrm{wt} . \%$, on the physical properties (apparent porosity and bulk density), microstructure and microhardness were investigated in details. The apparent porosity and bulk density were determined by water displacement method according to Archimedes rule, while the microstructure was investigated by scanning electron microscope. The Microhardness was measured by Vickers tester. The results showed that the physical properties and microstructure were improved after increasing the amount of added zircon or aluminum dross. Moreover, the hardness of sintered composites was increased with increasing both zircon and aluminum dross. The hardness of zircon containing composites was lower than the hardness of aluminum dross containing composites. The maximum hardness values were obtained for Al/10\% zircon (472 $\mathrm{MPa}$ ) and $\mathrm{Al} / 20 \%$ aluminum dross $(532 \mathrm{MPa})$
\end{abstract}

(C) 2021 Published by Published by Faculty of Engineering - Sohag University. DOI: 10.21608/SEJ.2021.72590.1001

Keywords: Al-base composite; Zircon; Aluminium dross; Sintering; Hardness.

\section{INTRODUCTION}

Composite is composed of two or more materials with significant properties which are different from that of individual components [1-3]. When the matrix is a metal, the composite is termed a metal matrix composite (MMC). In MMCs, the reinforcement is usually in the form of fiber, particulate, or whisker. It might be an intermetallic, ceramic-oxide, or none-oxides as carbide and nitride. The particulate reinforced composites are the most broadly utilized and the cheapest ones [2,4-6]. The fiber-reinforced composite has relatively higher mechanical properties. The incorporating of strong fiber in soft/ductile matrix leads to transfer the load to the fibers. The matrix also provides protection to fibers from external loads and atmosphere [7-9]. Structural composites are those in which the reinforcement is in the form of sheets instead of fiber or particles. These are further divided into two categories i.e., laminated and sandwich composites [10]. The common approaches to produce that composite contain powder metallurgy, diffusion bonding, liquid phase sintering, squeeze-infiltration, and stir-casting. The choice of appropriate processing procedure depends upon application area, quality, and distribution of reinforcement. It is probable to get diverse characteristics profile of composite by varying the manufacturing, processing and finishing methods even for the same amount and composition of constituents. The constituents of a metal matrix composite are usually processed separately, and then bonded with each other [3-4, 11-13]. MMCs reinforced with ceramics particles combine both metallic properties (ductility and toughness) and ceramic properties (high strength, high wear resistance and modulus) with the ability to be applied at high temperature compared to the un-reinforced matrix alloys. These kinds of composites can be applied in structural applications as aerospace, automotive industries, electronic and electrical industries, heavy machinery, military, and transportation. In the last two decades, these composites have earned more attention due to the accessibility of low-cost reinforcements and cost-effective processing routes which can provide reproducible properties $[5,6]$.

\footnotetext{
" Corresponding author: mzawrah@hotmail.com
} 
The properties of MMCs depend on the properties of matrix-material, reinforcement, and the matrixreinforcement interface [7].

Powder metallurgy (PM) is an interesting manufacturing technique can be used to produce low-cost, accurate and complex parts in large quantity which cannot produce by higher cost conventional methods that need wasteful secondary machining operations. In PM process, fine powders of the matrix and reinforcement are combined and pressed to get the desired shape, then sintered in ambient conditions [14-16]. In this method the particles should be homogeneously distributed to obtain excellent microstructure [17].

Aluminum-matrix composites reinforced with particulate have earned a significant attention in different structural applications since they have excellent mechanical properties [18-20]. They are usually fabricated by PM and casting methods, but the former tool is the preferable one since it gives homogenous material than the last one [21-24]. Reinforcement segregation, clustering, high localized residual porosity, and poor interfacial bonding are the main problems found in the other processing techniques [25]. The aluminum-containing composites have some valuable properties as low-density, high-conductivity, high-toughness and low-price in compared to other metals as magnesium [26-27]. Ceramic particulates e.g., $\mathrm{Al}_{2} \mathrm{O}_{3}, \mathrm{SiC}$, $\mathrm{TiC}$ and zircon, have been utilized to improve the properties of aluminum composites even at high temperatures [28-33]. Zircon is a ceramic material with high chemical stability, corrosion resistance and excellent thermal shock resistance. [33-34]. In the present work, the effect of zircon and aluminum dross particulates on the sinterability and properties of aluminum matrix composites is the main goal.

\section{MATERIAL AND EXPERIMENTAL METHODS}

\subsection{Materials}

Pure aluminum, zircon and aluminum dross (waste material) were used to fabricate the aluminum matrix composites. Aluminum dross was provided by the Egyptian company for aluminum, Nagee Hammady, Egypt. It is a waste material produced as a by-product after aluminum industry. Its main constituents are $\mathrm{Al}_{\text {and }} \mathrm{Al}_{2} \mathrm{O}_{3}$ in presence of some traces of $\mathrm{SiO}_{2}, \mathrm{MgO}$ and sodium [24]. The properties of supplying source for zircon and $\mathrm{Al}$ powders used in the current study are illustrated in Table 1.

TABLE 1: PROPERTIES OF AL AND ZIRCON POWDERS

\begin{tabular}{|c|c|c|c|c|c|}
\hline $\begin{array}{l}\text { Metal } \\
\text { powder }\end{array}$ & Purity, \% & $\begin{array}{c}\text { Particle size, } \\
\text { mesh }\end{array}$ & $\begin{array}{c}\text { Density, } \\
\left(\mathrm{g} / \mathrm{cm}^{3}\right)\end{array}$ & $\begin{array}{c}\text { Melting } \\
\text { point, }{ }^{\circ} \mathrm{C}\end{array}$ & Supplier \\
\hline Al & 99.9 & $100-200$ & 2.7 & 660 & Dop Organic Chemic \\
\hline Zircon & 99 & $100-200$ & 4.65 & 2550 & Ltd Company, Turkey \\
\hline
\end{tabular}

\subsection{Experimental procedures}

In the present study, aluminum matrix composites were prepared by powder metallurgy technique using the aforementioned raw materials. Different percentages of zircon i.e., 2, 4, 6, 8 and 10\% and aluminum dross i.e., 5 , 10,15 and $20 \%$ were used to prepare the designed aluminum matrix composites. Appropriate quantities of pure aluminum, zircon and aluminum dross powders were weighed using four digits accuracy electronic balance $(0.0001 \%$ accuracy). The powders were mixed in electric $\mathrm{V}$ mixer for 12 hours. Cold pressing of the mixed powders was performed for each sample by using the hydraulic press machine type Matest Italy/C055d under pressure of $300 \mathrm{MPa}$ in cylindrical steel die having diameter of $8 \mathrm{~mm}$. The pressed specimens were sintered at $500^{\circ} \mathrm{C}$ in tube furnace type GSL1600X for $120 \mathrm{~min}$ in argon atmosphere to prevent the aluminum oxidation process. The bulk density and apparent porosity of sintered composites were measured by liquid displacement method according to Archimedes' principle. Phase identification was performed by x-ray diffraction technique using diffractometer type PanalyticalX'Pert PRO-system with target $\mathrm{Cu}-\mathrm{K} \alpha$ and diffraction angle $2 \theta$ in the range $20-100^{\circ}$ at a rate of $3^{\circ} \mathrm{min}^{-1}$. The microstructural feature was investigated by scanning electron microscope model "SEM-Quanta FEG 250" attached with EDAX unit. Before testing the microstructure, all surfaces and edges of the specimens were wet ground using the suitable silicon carbide papers by standard grinding and polishing technique using a Buhlertm machine followed by polishing by diamond past of $6 \mu \mathrm{m}$. The Vickers microhardness tests were conducted for sintered specimens using nova 240 microhardness tester (NOVA TEST made in Japan Co., Ltd.) with a contact load of $10 \mathrm{~g}$ according to ASTM E384-11 standard test method at a temperature of $25 \pm$ $3^{\circ} \mathrm{C}$ using a diamond indenter with a steady load. 


\section{RESULTS AND DISCUSSION}

\subsection{Powders characteristics}

Figs. 1, 2 and 3 show X-ray diffraction patterns of Al, zircon and aluminum dross powders, respectively. For the patterns of $\mathrm{Al}$ and zircon Figs. 1 and 2, it obviously indicated that all peaks of pure aluminum and zircon are identified without any peaks for foreign phases. The pattern of aluminum dross in Fig. 3 exhibits peaks of rhombohedral crystal structure for corundum $\left(\alpha-\mathrm{Al}_{2} \mathrm{O}_{3}\right)$ [35], peaks of face-centered cubic (FCC) phase of aluminum [36-37] and peaks of hexagonal crystal structure Andalusite $\left(\mathrm{Al}_{2} \mathrm{SiO}_{5}\right)$ [38].

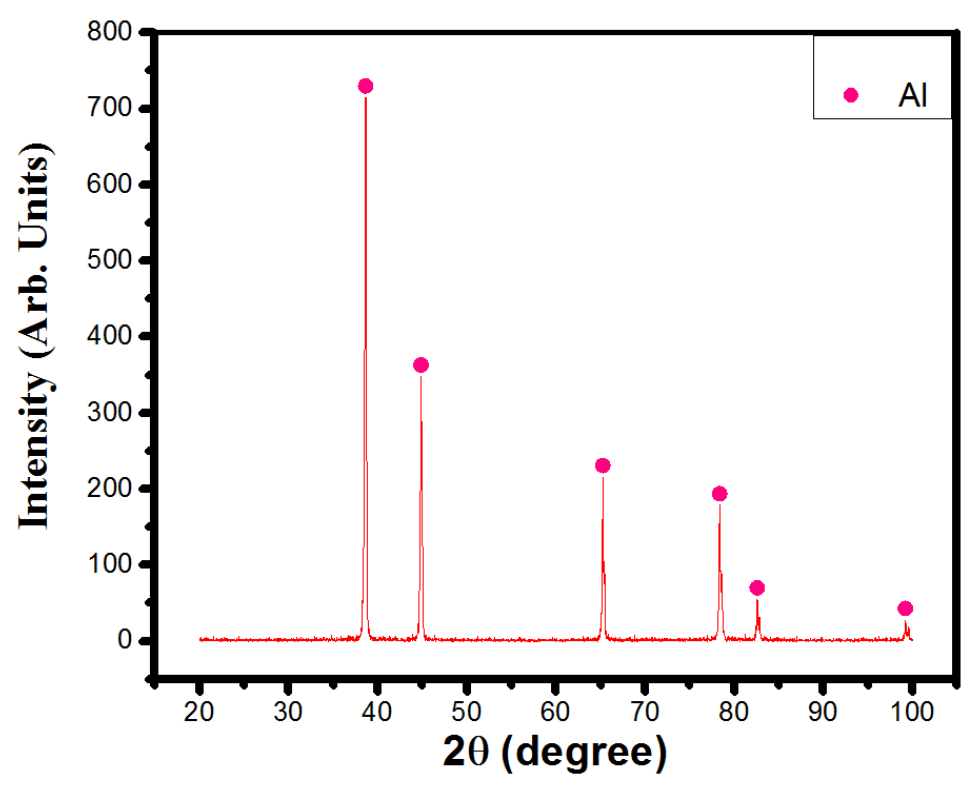

Fig. 1. XRD pattern of pure aluminum.

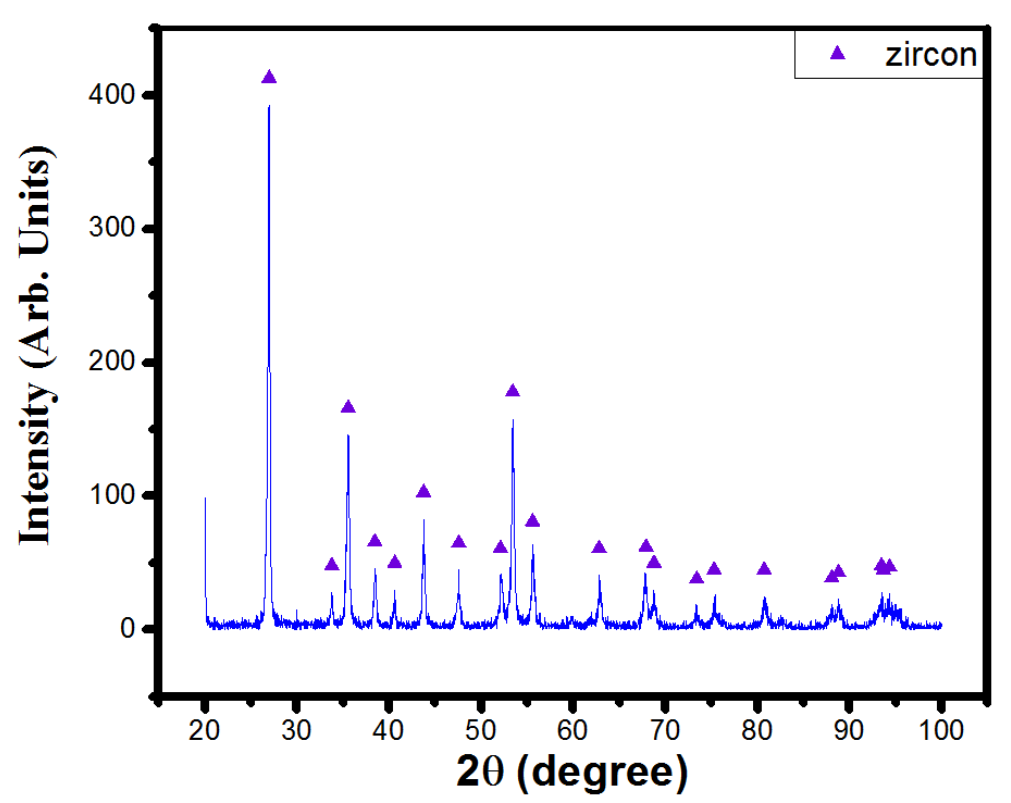

Fig. 2. XRD pattern of zircon. 


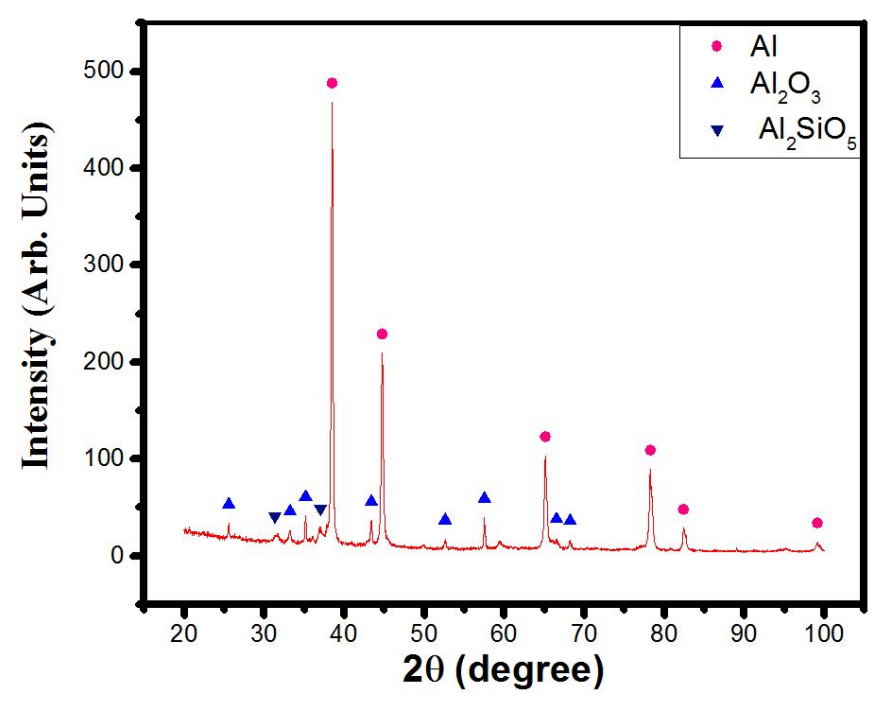

Fig. 3. XRD pattern of aluminum dross.

\subsection{Properties of sintered composites}

\subsubsection{Phase composition of sintered composites}

Fig. 4 shows X-ray diffraction patterns of Al-zircon composites that contain 2 and $10 \mathrm{wt} .-\%$ zircon sintered at $500^{\circ} \mathrm{C}$. After sintering process, no phase changes are indicated, and no new phases are formed. The peaks of $\mathrm{Al}$ and zircon are exhibited in the patterns. The peaks of zircon are appeared only in the pattern that contains $10 \%$ zircon. In the other pattern, the zircon content (2\%) is under the limit of XRD system to be detected. On the other hand, Fig. 5 displays X-ray diffraction patterns of Al-aluminum dross composites that contain 5 and $20 \mathrm{wt} \%$ aluminum dross. Also, no phase changes and new phases are detected in the patterns after the sintering process. The peaks $\mathrm{Al}_{2} \mathrm{O}_{3}$ are appeared in small amount in the pattern that contains $20 \%$ aluminum dross.

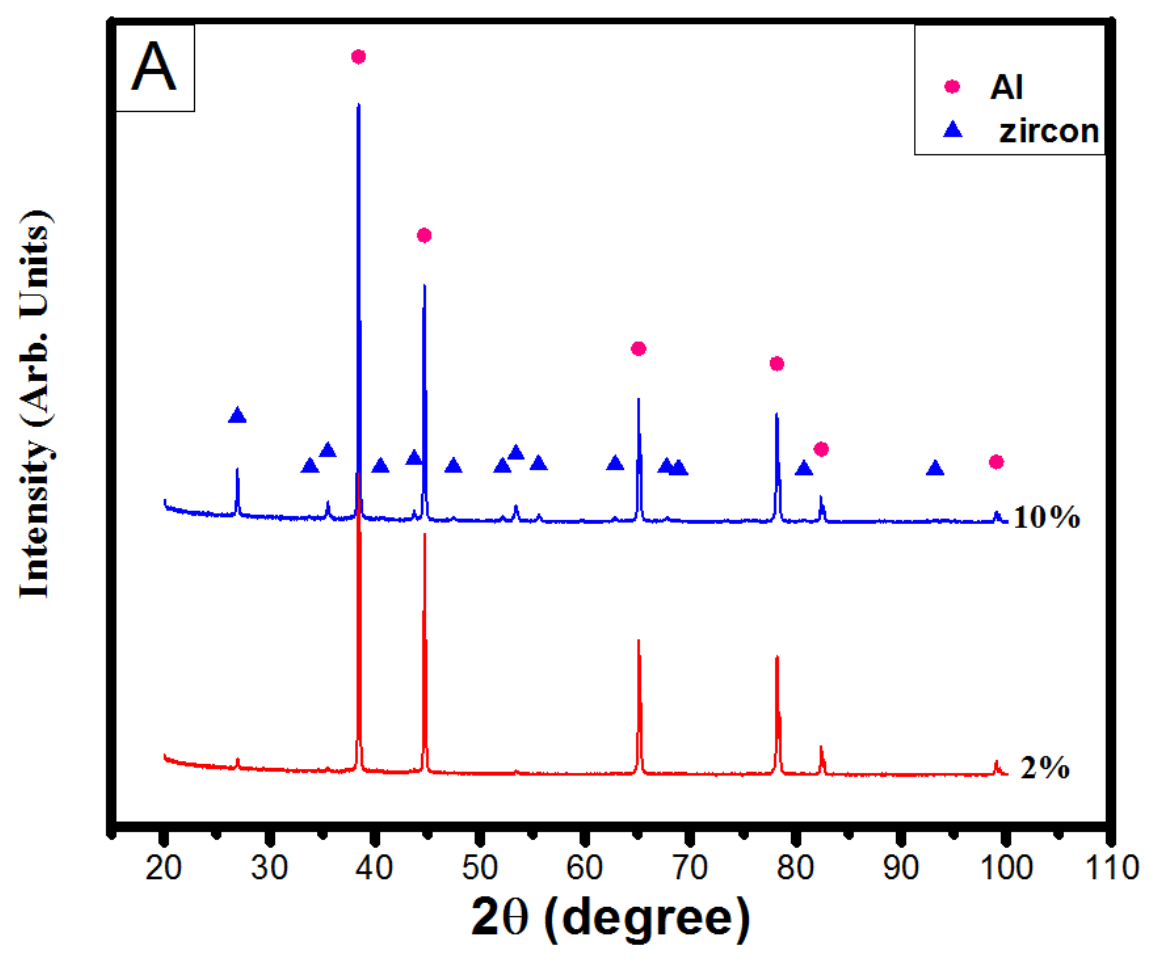

Fig 4. XRD patterns of sintered composites that contain 2 and 10 wt. \% zircon. 


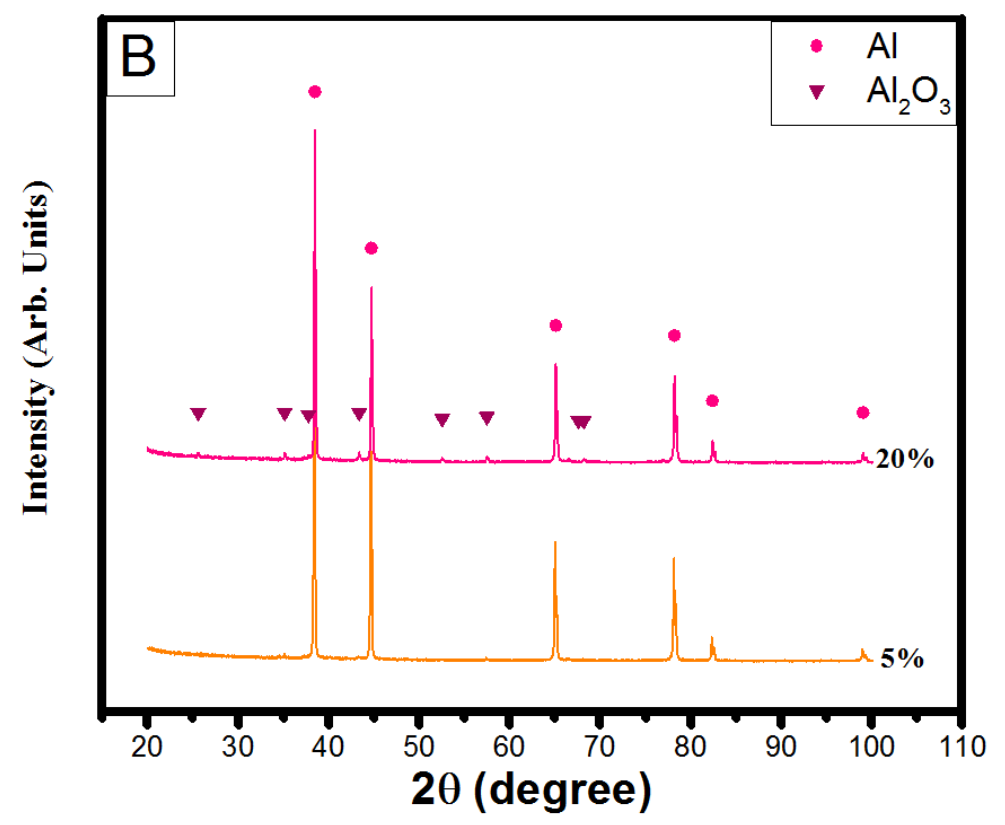

Fig. 5. XRD patterns of sintered composites that contains 5 and $20 \mathrm{wt}$ \% aluminum dross.

\subsubsection{Bulk density and apparent porosity of sintered composites}

Fig. 6 shows the bulk density of $\mathrm{Al} /$ zircon and $\mathrm{Al} /$ aluminum dross composites sintered at $500^{\circ} \mathrm{C}$. On the other hand, the apparent porosity of these composites is shown in Fig. 7. It can be seen that the bulk density increases with increasing the percentages of added zircon and aluminum dross. Gradual increase in the bulk density is detected in case of addition aluminum dross while sharp increase is indicated after addition of $2 \%$ zircon then gradual increase is appeared for all other percentages of zircon. The increase in bulk density with increasing the amount of zircon and aluminum dross is due to two reasons; firstly, the $\mathrm{ZrO}_{2}$ in $\mathrm{ZrSiO}_{4}$ (zircon) and $\mathrm{Al}_{2} \mathrm{O}_{3}$ in aluminum dross have higher density than $\mathrm{Al}$ (base of the composites). Secondly, during sintering at $500^{\circ} \mathrm{C}$, the atoms diffusion and grain-grain interaction lead to close the pores and increasing the density [39-41]. It seems that the addition of zircon and aluminum dross facilitate the atoms diffusion and the interaction between the grains $[33,42]$. This feature is appeared in Fig. 7 which displays the relationship between the apparent porosity and zircon or aluminum dross content. The trend of porosity goes in opposite trend of bulk density. The apparent porosity of $\mathrm{Al}$ sintered at $500^{\circ} \mathrm{C}$ is about $12.4 \%$; it decreased to about $9 \%$ after addition of zircon or aluminum dross [43]. Similar trend for bulk density results have been reported for Al/zircon composites by the authors in ref. [33]. In that study they indicated that the bulk density increases with increasing the amount of zircon content after sintering at 600 and $650^{\circ} \mathrm{C}$ and after adding up to $30 \mathrm{wt} \%$ of zircon. It has also been reported by Zawrah et al. that the addition of ceramic particles to metal-base composite has positive effect on physical and mechanical properties [44-46].
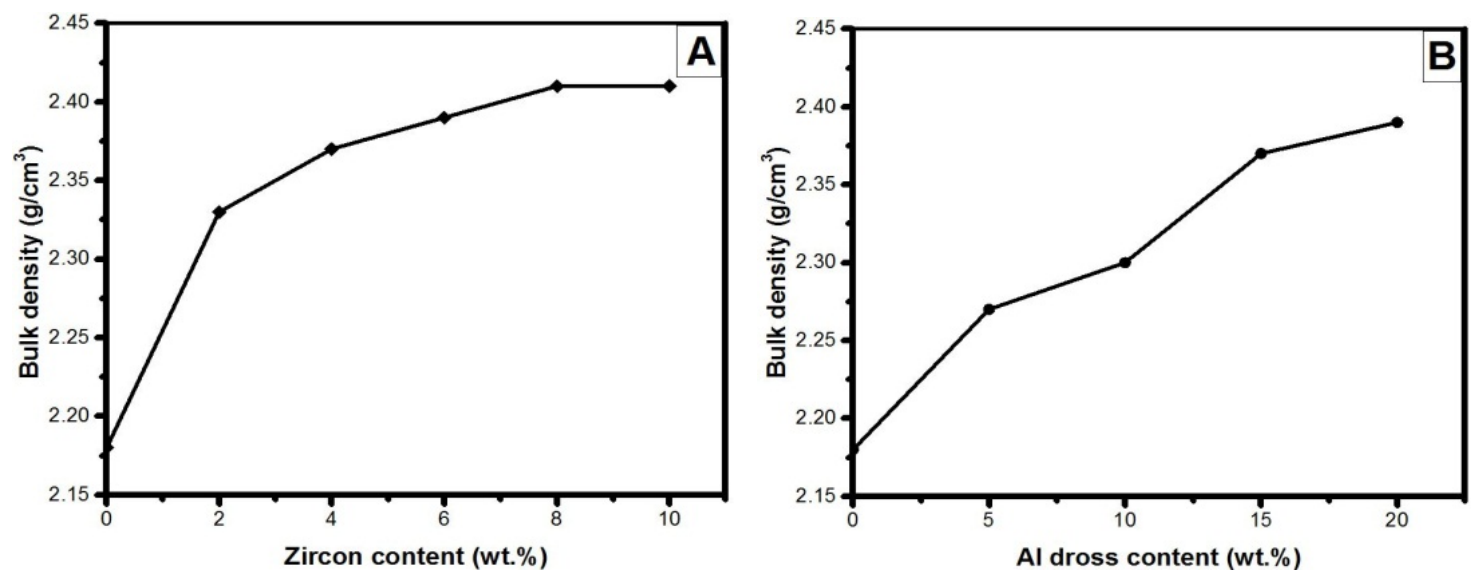

Fig. 6. Effect of zircon and aluminum dross on bulk density of Al-matrix composites sintered at $500^{\circ} \mathrm{C}$ 

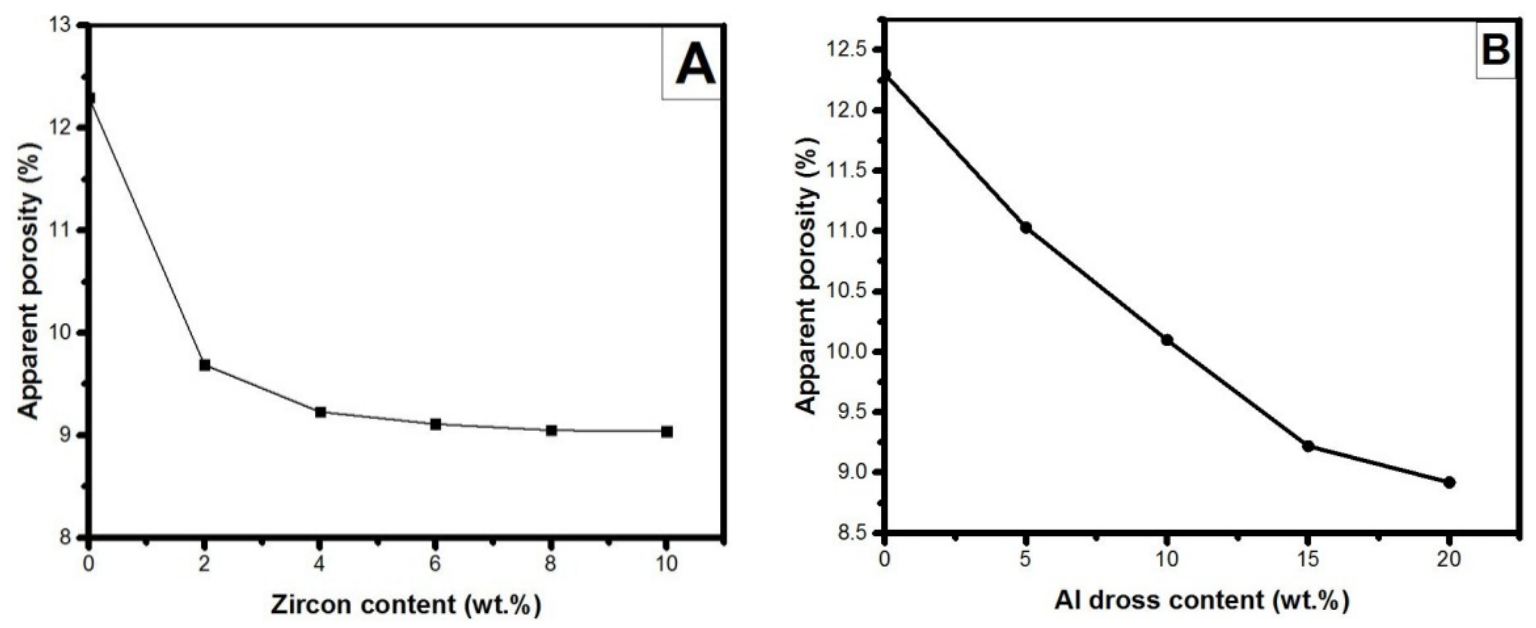

Fig. 7. Effect of zircon and aluminum dross on apparent porosity of Al-matrix composites sintered at $500^{\circ} \mathrm{C}$

\subsubsection{Microstructural analysis of sintered composites}

Figs. 8 - 12 show SEM images (different magnifications) of pure aluminum, $\mathrm{Al} / 2 \%$ zircon, $\mathrm{Al} / 10 \%$ zircon, $\mathrm{Al} / 5 \%$ aluminum dross, $\mathrm{Al} / 20 \%$ aluminum dross composites sintered at 500 , respectively. On the other hand, the EDAX spectra of $\mathrm{Al} / 10 \%$ zircon and $\mathrm{Al} / 20 \%$ aluminum dross composites are displayed in Fig. 13. It is indicated from Fig. 8 that the microstructure of sintered aluminum is homogenous with some voids and pores (dark-gray color). The aluminum grains seem to be elongated and tend to defuse with undefined edges. After addition of 2 and $10 \%$ zircon (Figs. $9 \& 10$ ), the pores and voids are decreased, and the microstructure maintain homogenous with decreasing the grain size. The pores and grain size of the composite that contain $10 \%$ zircon are smaller than those composites contain 0.0 and $2 \%$ zircon. The zircon particles are well distributed in the matrix and seem to be agglomerated in some places. Such kind of microstructure which has low grain size and low porosity will reflect on the other properties especially the mechanical properties. For the microstructure of $\mathrm{Al} / 5 \%$ aluminum dross and $\mathrm{Al} / 20 \%$ aluminum dross composites sintered at 500 (Figs. 11 and 12), since the aluminum dross is composed mainly of $\mathrm{Al}, \mathrm{Al}_{2} \mathrm{O}_{3}$ and some impurities as $\mathrm{SiO}_{2}$, the microstructure contains only the aluminum grains with some edged alumina grains. These grains are well distributed in the aluminum matrix and lead also to decrease the grain size of aluminum matrix. The composite that contains $20 \%$ aluminum dross exhibits lower porosity and lower grains size (Fig 12) as compared to the composite that contains 5\% aluminum dross. These results will reflect on the mechanical properties. The area chemical analyses for $\mathrm{Al} / 10 \%$ zircon and $\mathrm{Al} / 20 \%$ aluminum dross composites as conducted by EDAX are shown in the spectra presented in Fig. 13. It is appeared that the sintered $\mathrm{Al} / 10 \%$ zircon composite are composed mainly of $\mathrm{Al}, \mathrm{ZrO}_{2}$ and $\mathrm{SiO}_{2}$ while $\mathrm{Al} / 20 \%$ aluminum dross composite constitutes of $\mathrm{Al}, \mathrm{Al}_{2} \mathrm{O}_{3}$ and trace of $\mathrm{SiO}_{2}$. These results confirm the results obtained by XRD technique.
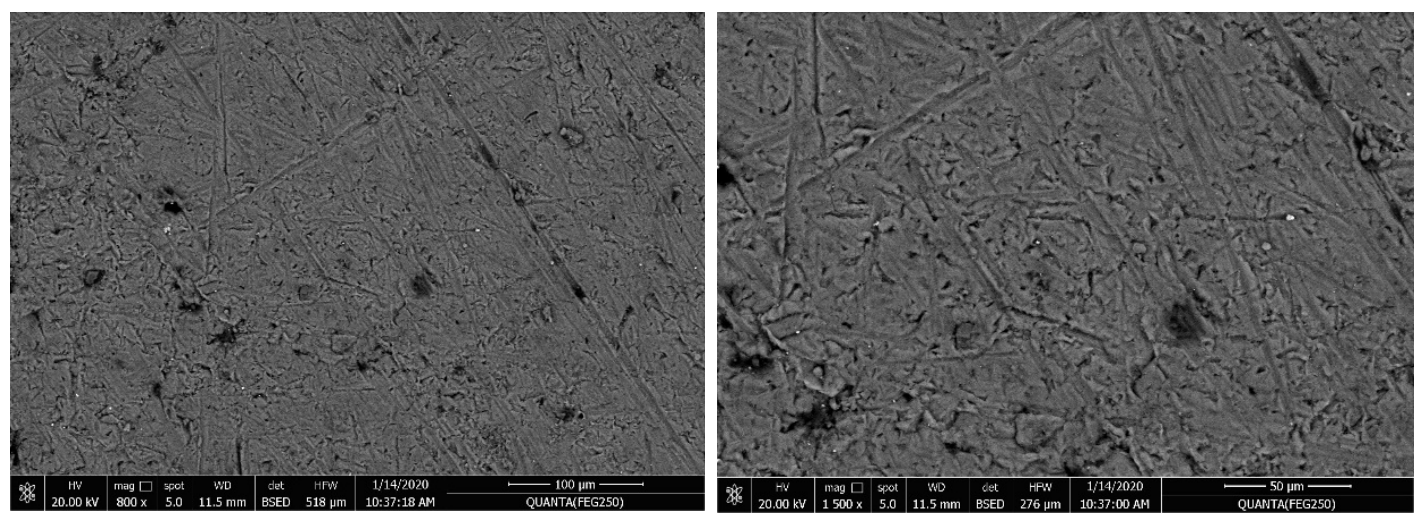

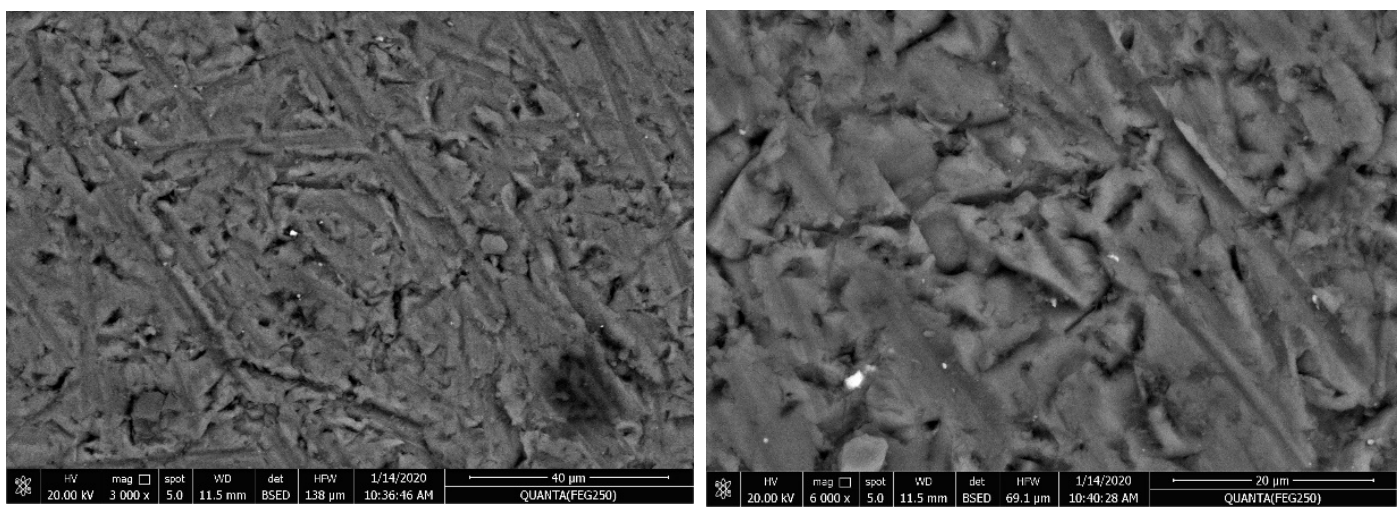

Fig. 8. SEM images (different magnifications) of pure $\mathrm{Al}$ sintered at $500^{\circ} \mathrm{C}$.
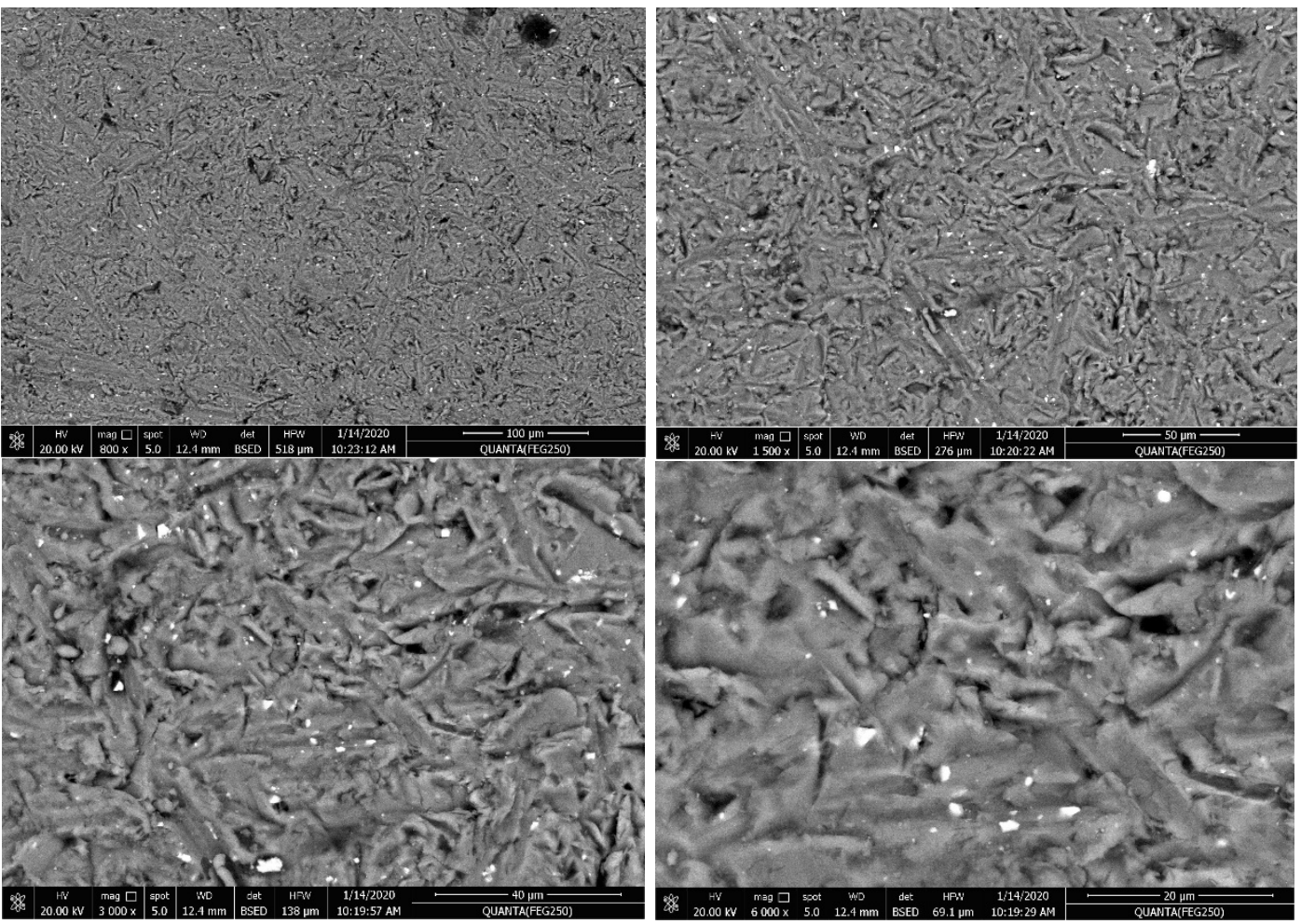

Fig. 9. SEM images (different magnifications) of $\mathrm{Al} / 2 \%$ zircon composite sintered at $500^{\circ} \mathrm{C}$.
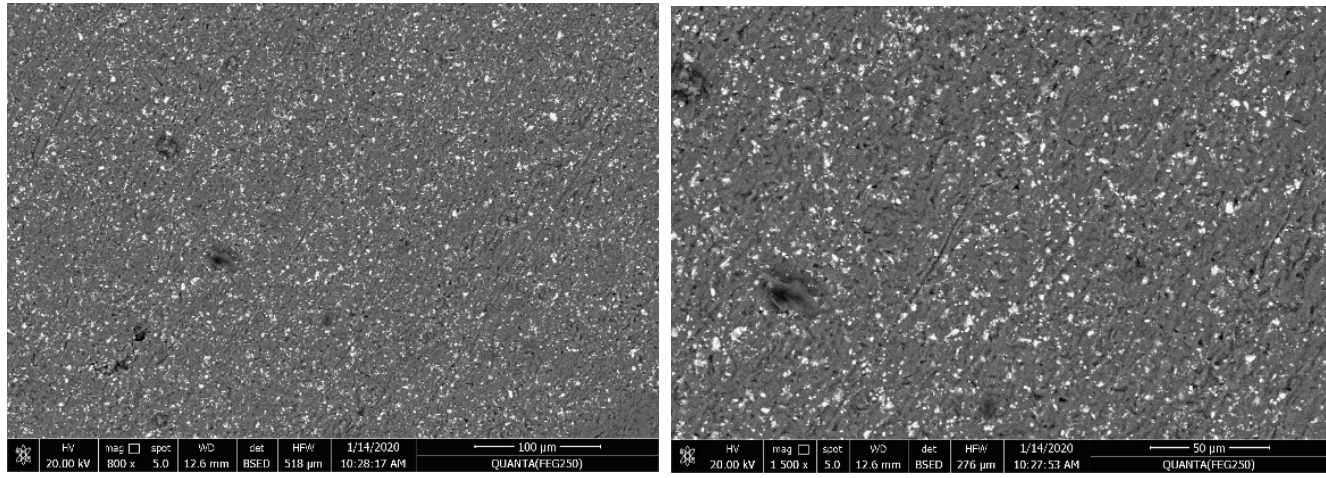

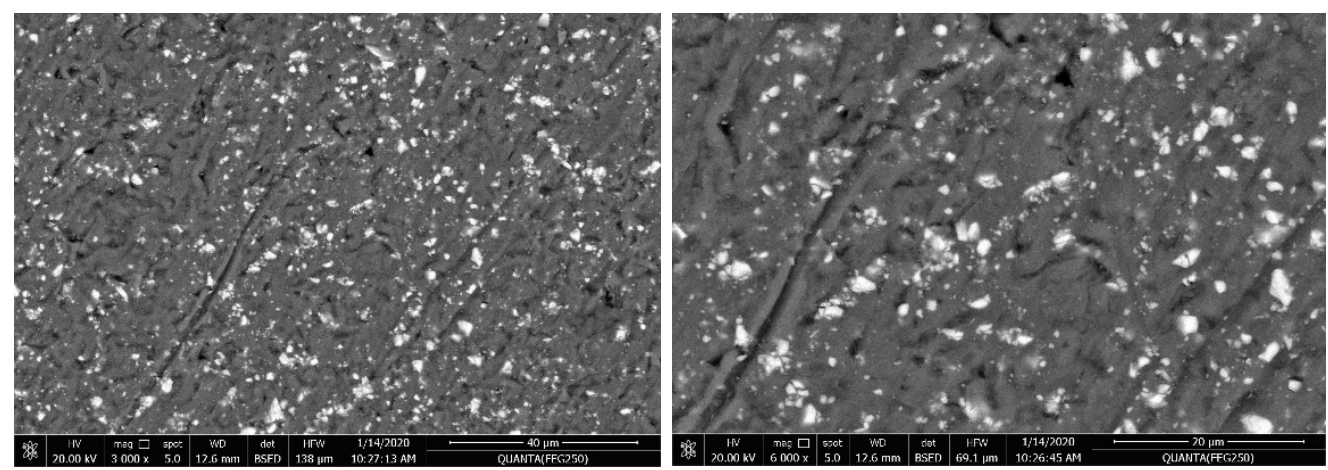

Fig. 10. SEM images (different magnifications) of $\mathrm{Al} / 10 \%$ zircon composite sintered at $500^{\circ} \mathrm{C}$
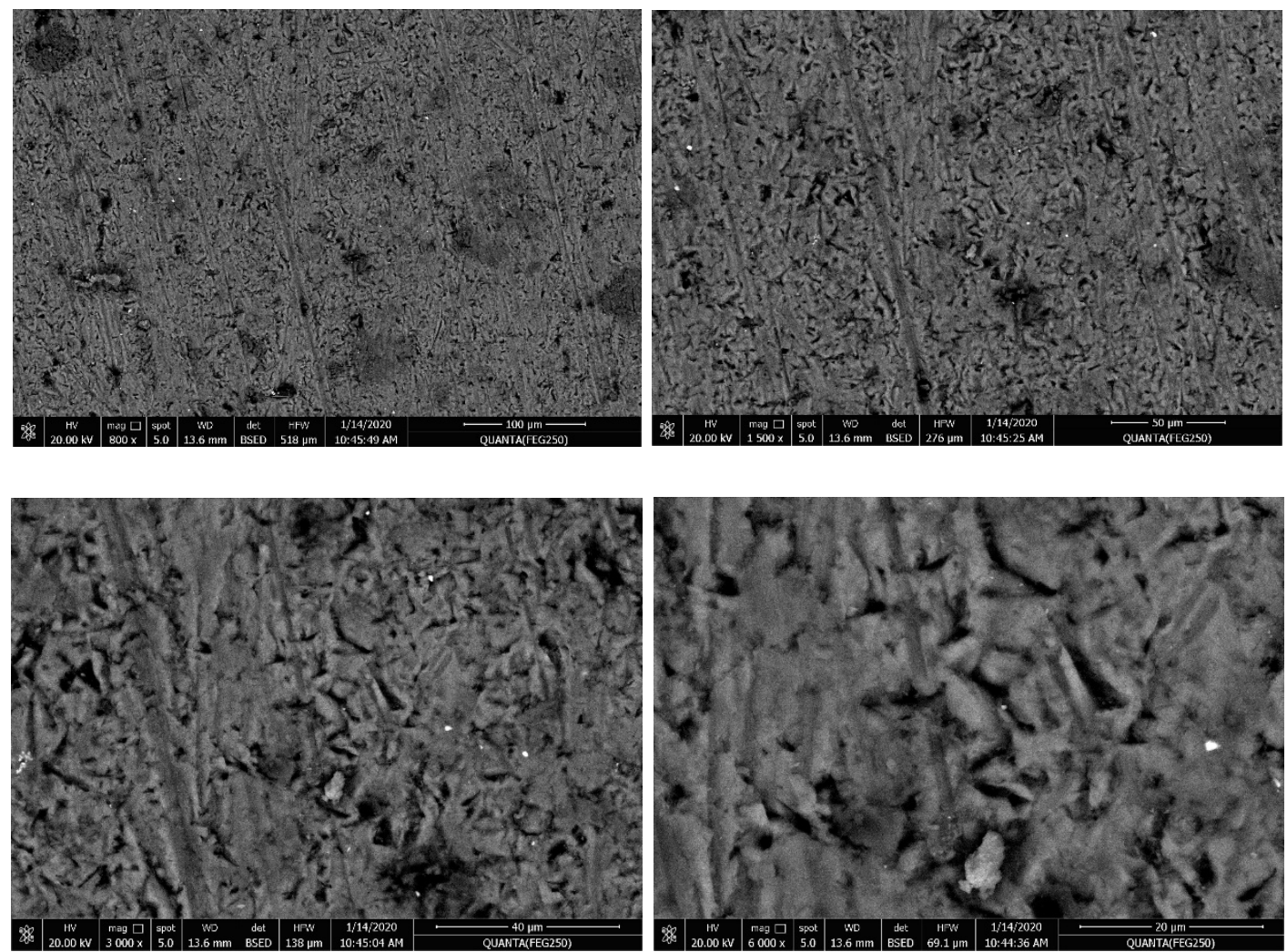

Fig. 11. SEM images (different magnifications) of $\mathrm{Al} / 5 \% \mathrm{Al}$-dross composite sintered at $500^{\circ} \mathrm{C}$.
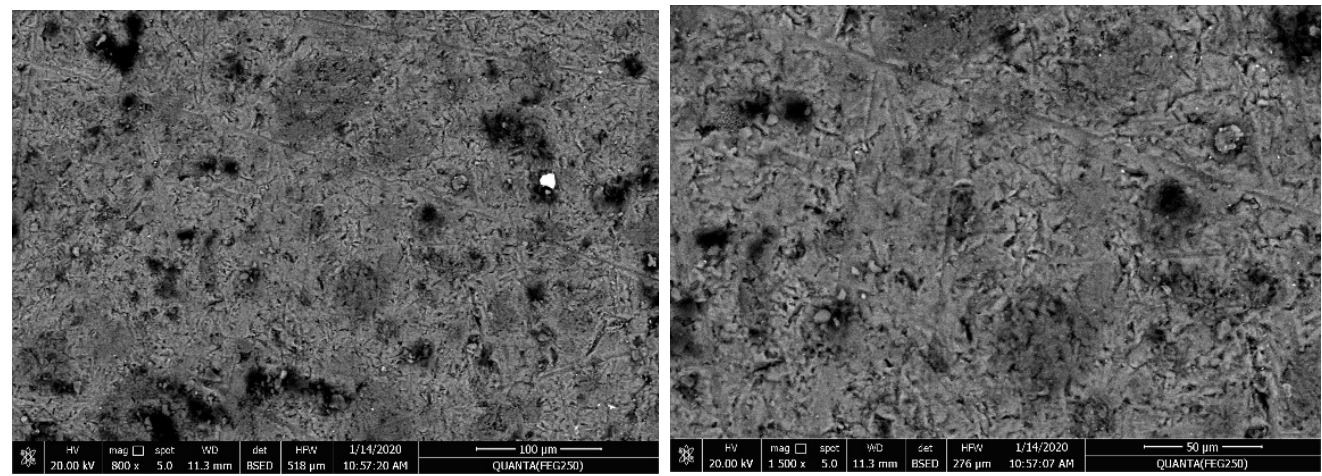

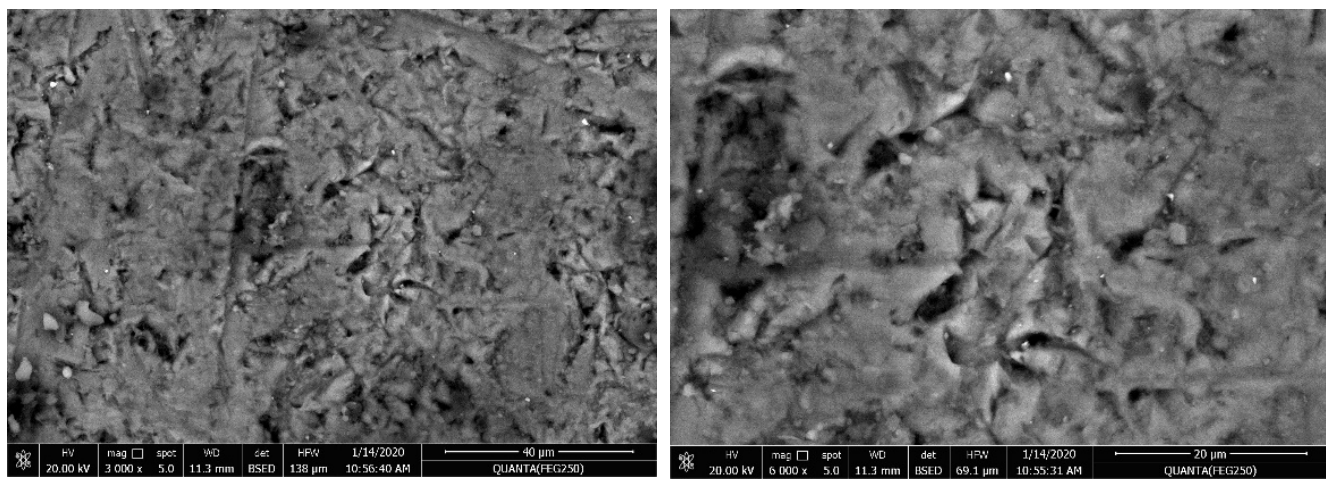

Fig. 12. SEM images (different magnifications) of $\mathrm{Al} / 20 \% \mathrm{Al}$-dross composite sintered at $500^{\circ} \mathrm{C}$.

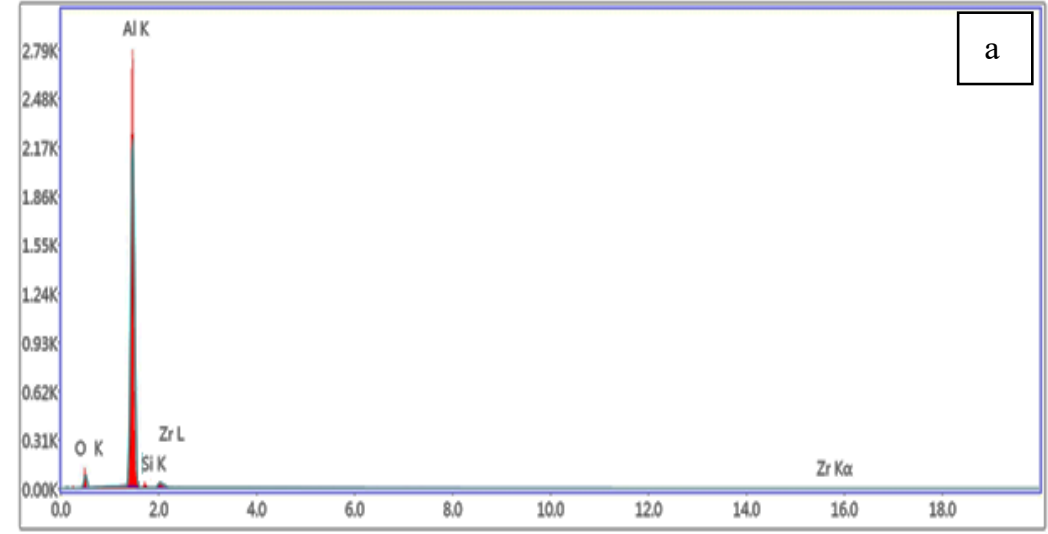

Lsec: 30.00 Cnts 0.000 kev Det Octane Pro Det Reso

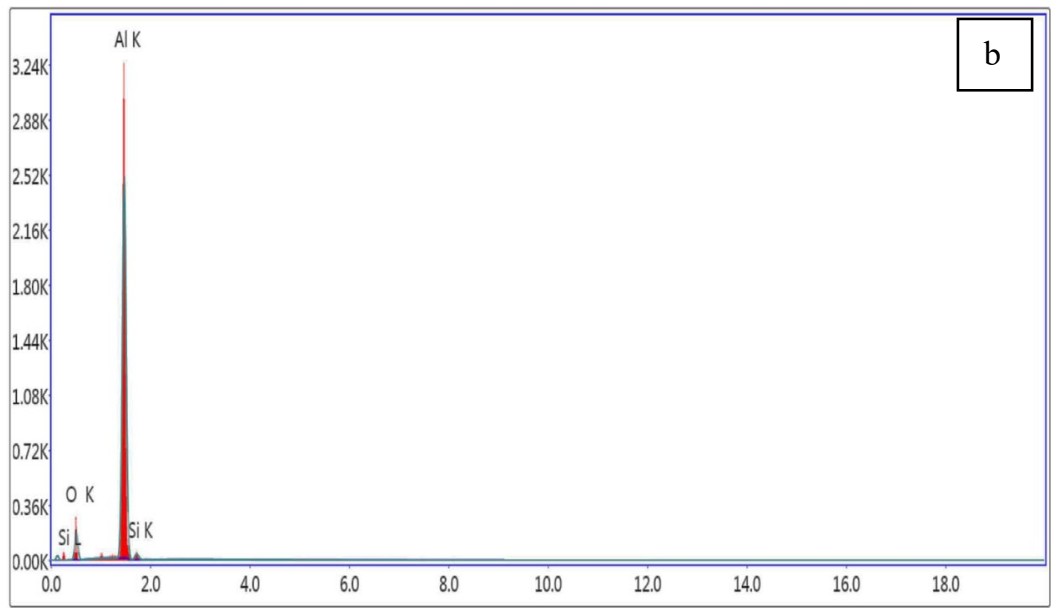

Lsec: 30.00 Cnts 0.000 keV Det: Octane Pro Det Reso

Fig. 13. EDAX spectra of $10 \%$ zircon (a) and $20 \%$ Al-dross (b) containing composites.

\subsubsection{Microhardness of sintered composites}

There are various factors affecting the mechanical properties of sintered metal-matrix composites. These are the reinforcement should be well-distributed in the matrix, the refinement of matrix grain size, lower porosity microstructure and types of phases formed in the composites [47-48]. Microhardness of Al/zircon and $\mathrm{Al}$ /aluminum dross composites sintered at $500^{\circ} \mathrm{C}$ is shown in Fig. 14. It is appeared that the hardness increases with increasing zircon and aluminum dross contents. Generally, the hardness of Al/zircon composites is relatively lower than the hardness of $\mathrm{Al} /$ aluminum dross composites due the lower content of zircon (up to $10 \%$ ) which contains $\mathrm{ZrO}_{2}$ and $\mathrm{SiO}_{2}$ as compared to the aluminum dross (up to 20\%) which contains $\mathrm{Al}$ and $\mathrm{Al}_{2} \mathrm{O}_{3}$. $\mathrm{Th}$ maximum hardness values are obtained for $\mathrm{Al} / 10 \%$ zircon (472 $\mathrm{MPa}$ ) and $\mathrm{Al} / 20 \%$ aluminum dross (532 $\mathrm{MPa}$ ). Here, the hardness depends on composition of composites, refinement of the grain size and porosity of the sintered composites. The addition of higher amount of zircon (10\%) and aluminum dross $(20 \%)$ leads to decreasing the grain size and porosity with increasing the amount of hard oxides in the matrix. It has been reported by several 
researchers that the hardness of aluminum composites was improved by addition of zircon or alumina. The existence of such hard oxides in the matrix leads to decrease the porosity, decrease the grain size and consequently increase the hardness $[33,49]$.
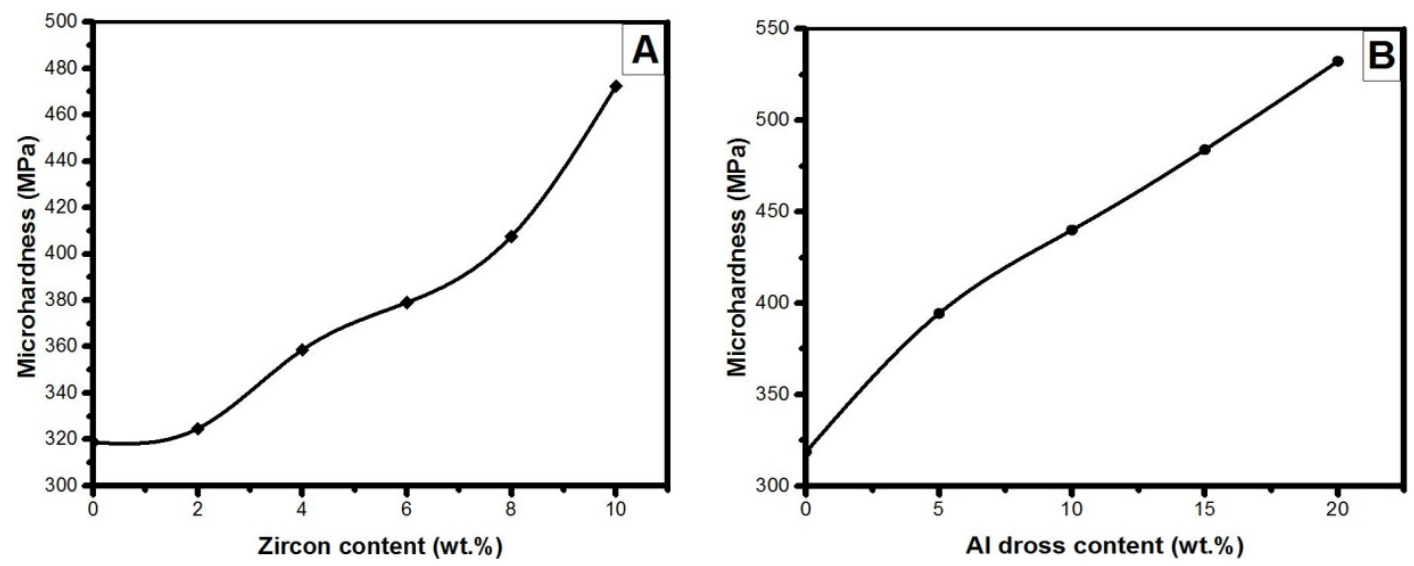

Fig. 14. Effect of zircon and aluminum dross on microhardness of Al-matrix composites sintered at $500{ }^{\circ} \mathrm{C}$.

\section{CONCLUSION}

In the present study, the following remarks were concluded:

1. $\mathrm{Al} /$ zircon and $\mathrm{Al} /$ aluminum dross composites with improved properties were successfully prepared by powder metallurgy and sintering at $500^{\circ} \mathrm{C}$ for $2 \mathrm{hrs}$.

2. Addition of zircon and aluminum dross led to improving the physical and mechanical properties of the prepared composites as compared to that of pure aluminum due to the refinement of grain size of the matrix, decreasing the porosity and excellent properties of their reinforcements as $\mathrm{ZrO}_{2}$ and $\mathrm{Al}_{2} \mathrm{O}_{3}$.

3. Due the incorporation of zircon and aluminum dross in the matrix of composites, improved hardness was obtained, and their values were increased with increasing the amount of zircon or aluminum dross. The maximum hardness was obtained for the composites $\mathrm{Al} / 10 \%$ zircon $(472 \mathrm{MPa}$ ) and $\mathrm{Al} / 20 \%$ aluminum dross (532 MPa).

\section{REFERENCES}

[1] K. Krishan Chawla, Composite Materials Science and Engineering, $3^{\text {rd }}$ Edition, Springer U.S.A, (2011) pp.3-99.

[2] D. Chung, Composite Materials: Science and Applications, $2^{\text {nd }}$ Edition, Engineering Materials and Processes, SpringerVerlag London, (2010) pp. 1-34.

[3] M. Awaad, M. F. Zawrah and N. M. Khalil, In Situ formation of Zirconia-Spinel-Mullite Ceramic Composites, Ceramics International, vol. 34, (2008) pp429-434.

[4] M. El-Baradie, Metal-matrix Composites: Fabrication Techniques and Applications, Advances in Materials and Processing Technologies, (1995) pp. 196-207.

[5] S. Tjong, Z. Ma, Microstructural and mechanical characteristics of in situ metal matrix composites, Materials Science and Engineering, Vol. 29, (2000) pp. 49-113.

[6] D. William, J. Callister, G. David, Materials Science and Engineering an Introduction, 8th edition., John Wiley \& Sons Inc., New York, (2010) pp. 647-657.

[7] B. Tia Tolle, H. Warren Hunt, ASM International Handbook-Composites, Introduction to Applications, Vol.21 (2001) pp. 2321-2524.

[8] A. Kaw, Mechanics of Composite Materials, $2^{\text {nd }}$ Edition, Taylor \& Francis Group, LLC, (2006) pp. 40-46.

[9] S. Y. Fu, B. Lauke, Y. W. Mai, Science and Engineering of Short Fiber Reinforced Polymer Composites, $3^{\text {rd }}$ Edition, (2012) pp.1-12, 2012.

[10] P. Mikell, Fundamentals of Modern Manufacturing: Materials, 4th Edition, Processes and Systems, (2010) pp.187-201

[11] Mohammed A. Taha, Amira H. Nassar, Mahmoud F. Zawrah, Improvement of Wetability, Sinterability, Mechanical and Electrical Properties of $\mathrm{Al}_{2} \mathrm{O}_{3}-\mathrm{Ni}$ Nanocomposites Prepared by Mechanical Alloying, Ceramics International 43 (2017) pp. 3576-3582

[12] M. F. Zawrah, Raghieba A. Essaway, Hamdia A. Zayed, Amira H. Abdel Fattah and Mahmed A. Taha, Mechanical Alloying, Sintering and Characterization of $\mathrm{Al}_{2} \mathrm{O}_{3}-20 \mathrm{wt} .-\% \mathrm{Cu}$ Nanocomposites, Ceramics International 40 (2014) pp. 31-38.

[13] M. F. Zawrah, H. Ahmed and N. E. El-Baly, Fabrication of $\mathrm{Al}_{2} \mathrm{O}_{3}-20$ Vol.\% Al nanocomposite powder using high energy milling, Materials Research Bulletin, 47 (2012) 655-661.

[14] S. Suresh, A. Mortensen, Fundamentals of Metal Matrix Composites, Library of Congress Cataloging, Vol. 24 (1993), pp.3-22.

[15] T. Clyne, Metal-Matrix Composite: Matrices and Processing, Encyclopedia of Materials: Science and Technology, Elsevier, 2001. 
[16] Sharma Pardeep, Khanduja Dinesh, Sharma Satpal, Tribological and mechanical behavior of particulate aluminum matrix composites, Journal of Reinforced Plastics and Composites, 33 (2014), pp. 2192-2202.

[17] J. M. Torralba, C. E. Costa da, F. Velasco, P/M aluminum matrix composites: an overview. Journal of Materials Processing Technology, 133 (2003), pp. 203-206.

[18] C. Padmavathi, A. Upadhyaya, D. Agrawal, Effect of sintering temperature and heating mode on consolidation of Al$7 \mathrm{Zn}-2.5 \mathrm{Mg}-1 \mathrm{Cu}$ aluminum alloy, Bulletin of Materials Science, 35(5) (2012) pp. 823-832.

[19] E. Ghasali, M. Alizadeh, T. Ebadzadeh, A. H. Pakseresht, A. Rahbari, Investigation on microstructural and mechanical properties of $\mathrm{B}_{4} \mathrm{C}$-aluminum matrix composites prepared by microwave sintering, Journal of Materials Research and Technology, 4(4) (2015) pp.411-415.

[20] E. Ghasali, A. Pakseresht, F. Safari-kooshali, M. Agheli, T. Ebadzadeh, Investigation on microstructure and mechanical behavior of $\mathrm{Al}-\mathrm{ZrB} 2$ composite prepared by microwave and spark plasma sintering, Materials Science \& Engineering: A 627 (2015) pp.27-30.

[21] E. Ghasali, A. H. Pakseresht, M. Agheli, A. M. Marzbanpour, T. Ebadzadeh, WC-Co particles reinforced aluminum matrix by conventional and microwave sintering, Materials Research, 18(6) (2015) pp. 1197-1202.

[22] E. Ghasali, M. Alizadeh, T. Ebadzadeh, Mechanical and microstructure comparison between microwave and spark plasma sintering of Al-B 4 C composite, Journal of Alloys and Compounds, 655 (2016) pp.93-98.

[23] K. Shirvanimoghaddam, H. Khayyam, H. Abdizadeh, M. Karbalaei Akbari, A. H. Pakseresht, E. Ghasali, Boron carbide reinforced aluminum matrix composite: Physical, mechanical characterization and mathematical modeling, Materials Science and Engineering: A. 658 (2016) pp.135-149.

[24] Taha, M. A. Nasser, A. H., Zawrah, M. F., In-situ formation of composite having hard outer layer based on aluminum dross reinforced by $\mathrm{SiC}$ and $\mathrm{TiO}_{2}$, Construction and Building Materials, Volume 248, (2020), Article number 118638

[25] K. Kaur, O. P. Pandey, Microstructural characteristics of spray formed zircon sand reinforced LM13 composite, Journal of Alloys and Compounds, 503(2) (2010) pp. 410-415.

[26] S. P. Rawal, Metal matrix composites for space applications, JOM, 53(4) (2001) pp.14-17.

[27] A. R. K. Swamy, A. Ramesha, G. B. Veeresh Kumar, J. N. Prakash, Effect of particulate reinforcements on the mechanical properties of Al6061-WC and Al6061-Gr MMCs, Journal of Minerals and Materials Characterization and Engineering, 10(12) (2011) pp. 1141-1152.

[28] M. F. Zawrah, H. Ahmed and N. E. El-Baly, Fabrication of $\mathrm{Al}_{2} \mathrm{O}_{3}-20$ Vol.\% Al nanocomposite powder using high energy milling, Materials Research Bulletin, 47 (2012) 655-661.

[29] I. Kerti, Production of TiC reinforced-aluminum composites with the addition of elemental carbon, Materials Letters, 59(29-30), (2005) pp. 3795-3800.

[30] X. C. Tong, A. K. Ghosh, Fabrication of in situ TiC reinforced aluminum matrix composites, Journal of Materials Science, 36(16) (2001) pp. 4059-4069.

[31] A. R. I. Kheder, G. S. Marahleh, D. M. K. Al-Jamea, Strengthening of aluminum by $\mathrm{SiC}_{1} \mathrm{Al}_{2} \mathrm{O}_{3}$ and $\mathrm{MgO}$, Jordan Journal of Mechanical and Industrial Engineering, 5(6) (2011) pp. 533-541.

[32] E. Ghasali, A. Pakseresht, A. Rahbari, H. Eslami-shahed, M. Alizadeh, T. Ebadzadeh, Mechanical properties and microstructure characterization of spark plasma and conventional sintering of Al-SiC-TiC composites, Journal of Alloys and Compounds, 666 (2016) pp. 366-371.

[33] H. Abdizadeh, M. Ashuri, P. T. Moghadam, A. Nouribahadory, H. R. Baharvandi, Improvement in physical and mechanical properties of aluminum/zircon composites fabricated by powder metallurgy method, Materials \& Design, 32 (8-9) (2011), pp.4417-4423.

[34] R. S. Panwar, S. Kumar, R. Pandey, O. P. Pandey, Study of Non-lubricated Wear of the Al-Si Alloy Composite Reinforced with Different Ratios of Coarse and Fine Size Zircon Sand Particles at Different Ambient Temperatures, Tribology Letters, 55(1) (2014), pp.83-92.

[35] M. F. Zawrah, Mohammed A Taha, H. Abo Mostafa, In-situ formation of $\mathrm{Al}_{2} \mathrm{O}_{3} / \mathrm{Al}$ core-shell from waste material: production of porous composite improved by graphene, Ceramics International, Volume 44, Issue 9, (2018), pp.1069310699.

[36] Mohammed A. Taha, Amira H. Nassar, Mahmoud F. Zawrah, Improvement of Wetability, Sinterability, Mechanical and Electrical Properties of $\mathrm{Al}_{2} \mathrm{O}_{3}-\mathrm{Ni}$ Nanocomposites Prepared by Mechanical Alloying, Ceramics International 43 (2017), pp. 3576-3582.

[37] J. B. Burt, N. L. Ross, R. J. Angel, M Koch, Equations of state and structures of Andalusite to 9.8 GPa and Sillimanite to 8.5 GPa, Am. Mineral, 91 (2006) pp. 319-26.

[38] M. H. Elahinia, M. Hashemi, M. Tabesh, S. B. Bhaduri, Manufacturing and processing of NiTi implants: a review, Prog. Mater Sci. 57 (2012) pp. 911-46.

[39] Mohammed A. Taha, Rasha A. Youness, Mahmoud F. Zawrah, Review on nanocomposites fabricated by mechanical alloying, International Journal of Minerals, Metallurgy and Materials, Volume 26, Number

[40] M. F. Zawrah, I. M. Hassab-Allah, M. H. Ata, H. Shouib, Effect of $\mathrm{Si}, \mathrm{Al}_{2} \mathrm{O}_{3}$, and aluminum dross on sinterability and properties of Ni-Ti metal matrix composites prepared by powder metallurgy, Materials Research Express, 6(9),096588, 2019.

[41] Mohammed A. Taha, Mahmoud F. Zawrah, Mechanical Alloying and Sintering of Ni/10wt.\% $\mathrm{Al}_{2} \mathrm{O}_{3}$ Nanocomposites and Its Characterization, Silicon, Volume 10, Issue 4, 1 July 2018, pp. 1351-1359.

[42] M F Zawrah, Mohammed A. Taha, Fardous Saadallah, Ahamed Gamal Mostafa, Mohamed Yossry Hassan, Mahmoud Nasr, Effect of Nano $\mathrm{ZrO}_{2}$ on the Properties of $\mathrm{Al}_{-}-\mathrm{Al}_{2} \mathrm{O}_{3}$ Nanocomposites prepared by mechanical Alloying, Silicon, Volume 10, Issue 4, 1 July 2018, pp. 1523-1531.

[43] Y. L. Shen, N. Chawla, On the correlation between hardness and tensile strength in particle reinforced metal matrix composites, Mater Sci Eng A, 297 (2001) pp. 44-7.

[44] Mohammed A. Taha, Amira H. Nassar, M.F. Zawrah, Effect of milling parameters on sinterability, mechanical and electrical properties of $\mathrm{Cu}-4$ wt.\% $\mathrm{ZrO}_{2}$ nanocomposite, Materials Chemistry and Physics, Volume 181, 15 September 2016, pp. 26-32.

[45] M. F. Zawrah, Hamdia A. Zayed, Raghieba A. Essaway, Amira H. Abdel Fattah and Mahmed A. Taha, Preparation by mechanical alloying, characterization and sintering of $\mathrm{Cu}-20$ wt.- $\% \mathrm{Al}_{2} \mathrm{O}_{3}$ nanocomposites, Materials and Design 46 (2013), pp. 485-490. 
[46] M. F. Zawrah, H. Abo Mostafa, M. A. Taha, Effect of SiC content on microstructure, mechanical and electrical properties of Al-20Si-xSiC nanocomposites fabricated by mechanical alloying, Material Research Express, Vol. 6, No. 12, 2019, 125014.

[47] H. K. Kang, Microstructure and electrical conductivity of high volume $\mathrm{Al}_{2} \mathrm{O}_{3}$-reinforced copper matrix composites produced by plasma spray, Surf. Coat. Technol, 190 (2005) pp. 448-52.

[48] M. Alizadeh, M. M. Aliabadi, Synthesis behavior of nanocrystalline $\mathrm{Al}-\mathrm{Al}_{2} \mathrm{O}_{3}$ composite during low time mechanical milling process, J. Alloys Compd., 509 (2001) pp. 4978-86.

[49] M. F. Zawrah and M. H. Aly, In-Situ Formation of $\mathrm{Al}_{2} \mathrm{O}_{3}-\mathrm{SiC}-$ Mullite from Al-Matrix Composites, Ceramics International, 32, 1, pp. 21-28, 2006. 